\title{
Abnormal lymphocyte function precedes hyperglycaemia in mice treated with multiple low doses of streptozotocin
}

\author{
M. Itoh, M. Funauchi, K. Sato, S. Kisamori, N. Fukuma, Y. Hirooka and N. Nihei \\ Third Department of Internal Medicine, Hamamatsu University School of Medicine, Hamamatsu, Japan
}

Summary. To investigate early immunological disturbances at the onset of diabetes, lymphocyte function and islet cell surface antibodies were studied in streptozotocin-treated C57BL/10 and B10.BR mice. In C57BL/10 mice, streptozotocin given in multiple low doses depressed lymphoblastic transformation to phytohaemagglutinin and pokeweed mitogen, but not to concanavalin A on day 6 after the first administration. On day 20, the transformation remained suppressed with phytohaemagglutinin, but recovered to the control level with pokeweed mitogen. In the early phase after treatment, the islet cell surface antibodies were elevated and then declined. Single high dose administration depressed responses to phytohaemagglutinin with no detectable islet cell surface antibodies. In B10.BR mice transformations to pokeweed mitogen and concanavalin A were suppressed in the early phase. The strain of mice may be a factor to be considered. Thus, it was suggested that the deterioration of immunological function with the formation of islet cell surface antibodies preceded the onset of hyperglycaemia in mice treated with multiple low doses of streptozotocin.

Key words: Lymphocyte function, experimental diabetes, islet cell surface antibody, streptozotocin, mice, insulitis.
There are many reports suggesting that autoimmune reactions are involved in the pathogenesis of insulin-dependent diabetes. The presence of islet cell antibodies (ICA) [1-2] or islet cell surface antibodies (ICSA) [3] in an early phase of the disease suggests they may have a pathological role in the onset of diabetes.

Multiple administration of low doses of streptozotocin causes insulitis in mice which resembles human insulin-dependent diabetes [4], while single injections of high doses of streptozotocin cause degranulation and reduction in number of $\beta$ cells in the pancreatic islets without insulitis. To investigate the early immunological disturbances at the onset of insulin-dependent diabetes, lymphocyte function and ICSA were estimated in streptozotocin-treated animals.

\section{Materials and Methods}

Seven-to eight-week old male mice $\left(\mathrm{C} 57 \mathrm{BL} / 10\left[\mathrm{H}-2^{\mathrm{b}}\right]\right.$ and B10.BR $\left[\mathrm{H}-2^{\mathrm{k}}\right]$ ) were caged in groups of three to five with free access to water and standard mouse chow. On five consecutive days mice were given intraperitoneal injections of streptozotocin $(40 \mathrm{mg} / \mathrm{kg}$ body weight) dissolved in citrate buffer ( $\mathrm{pH} 4.5$ ) immediately before the administration. Single injections of high doses of streptozotocin $(200 \mathrm{mg} / \mathrm{kg}$ body weight) were administered to another group. Control animals received citrate buffer only. Treatment with streptozotocin was carried out using $36 \mathrm{C} 57 \mathrm{BL} / 10$ and $29 \mathrm{~B} 10 . \mathrm{BR}$ mice, while $32 \mathrm{C} 57 \mathrm{BL} / 10$ and 28 B10.BR were used as controls. Each group was separated into subgroups (Fig. 1, numbers in parentheses). On days 2, 6, 20 and 41 after the first injection of streptozotocin or citrate buffer, spleens and pancreases were removed after collection of blood. Blood glucose was analysed by autoanalyser.

Pancreases were fixed in formalin and embedded in paraffin, followed by staining with haematoxylin-eosin. Spleens were transferred to RPMI-1640 medium containing 10\% heat-inactivated fetal calf serum. After gentle homogenization, the tissue was filtered through 150 mesh followed by density gradient with Ficoll-paque. Lymphocytes $\left(200 \mu \mathrm{l} ; 5 \times 10^{6} / \mathrm{ml}\right)$ and $20 \mu \mathrm{l}$ of mitogen were incubated for $72 \mathrm{~h}$ in a humidified atmosphere containing $5 \% \mathrm{CO}_{2}$ at $37^{\circ} \mathrm{C}$. The final concentrations of phytohaemagglutinin (PHA), pokeweed mitogen (PWM), and concanavalin A were $1 \mu \mathrm{g} / \mathrm{ml}, 50 \mu \mathrm{g} / \mathrm{ml}$ and $5 \mu \mathrm{g} / \mathrm{ml}$. The islets and spleen cell homogenates were obtained from Wistar male rats and used at a concentration of $0.1 \mu \mathrm{g} / \mathrm{ml}$. $\left[{ }^{3} \mathrm{H}\right]-$ thymidine $(20 \mu \mathrm{l})$ was added $20 \mathrm{~h}$ before the harvest. Lymphocytes were solubilized and counted in a scintillator.

ICSA were measured by an indirect immunofluorescence method according to a modified method of Lernmark et al. [3]. Free islet cells $\left(1 \times 10^{5}\right)$ were incubated with $100 \mu$ l of inactivated test serum for $60 \mathrm{~min}$ at room temperature. After washing, cells were subsequently incubated with $100 \mu \mathrm{l}$ of fluorescein isothiocyanate (FITC)-conjugated goat anti-mouse $\operatorname{IgG}\left[\mathrm{F}\left(a b^{*}\right) 2\right]$ or $\operatorname{IgM}(\mu$-chain specific) for $30 \mathrm{~min}$ at room temperature. After washing, FITC-positive cells were counted under a fluorescent microscope. Sera which reacted with more than $10 \%$ of $50-100$ cells were evaluated as ICSA positive.

Statistical analyses were performed with the Student's t-test, $\chi^{2}$ testing and Wilcoxon's rank sum test. 


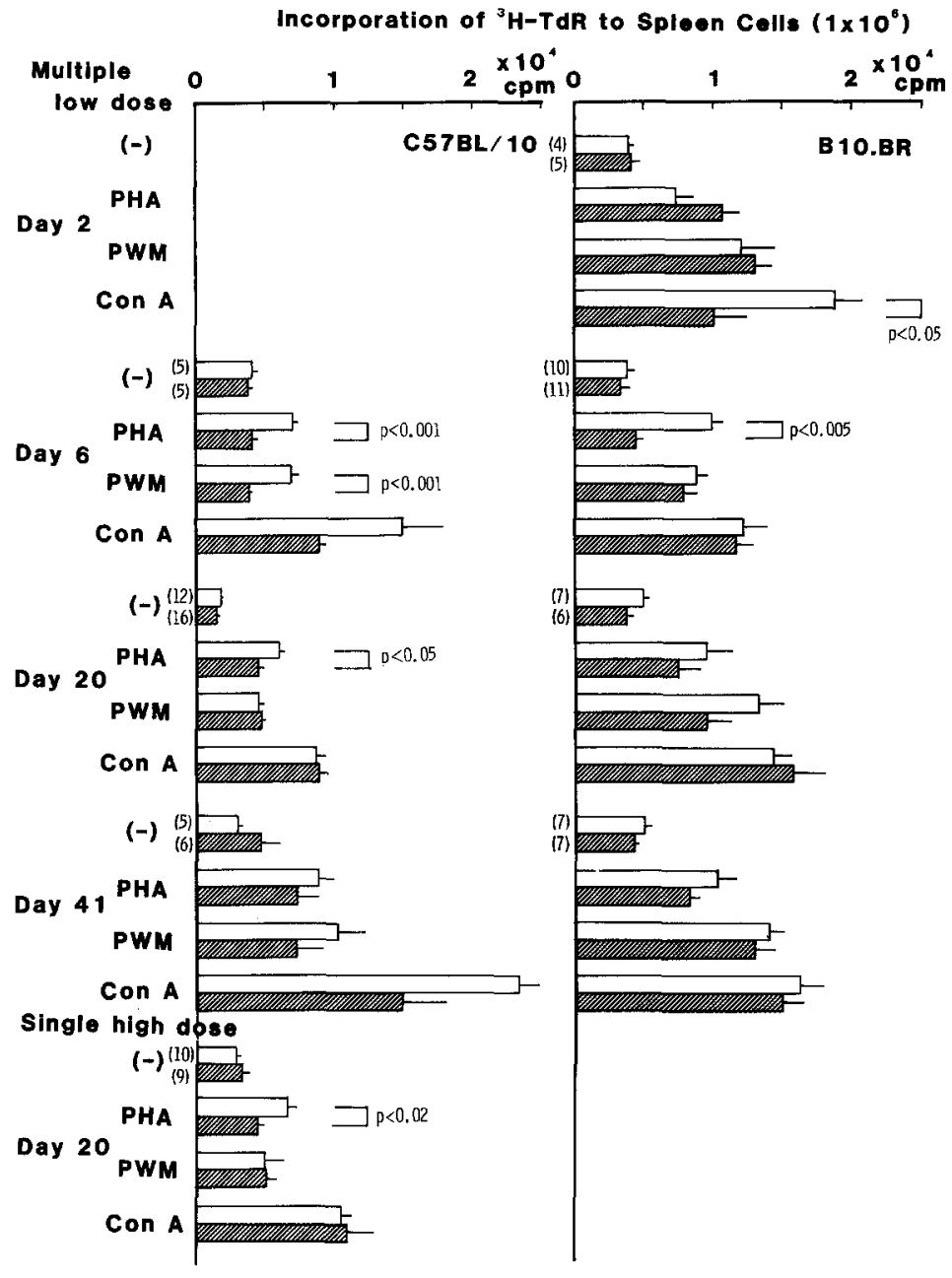

Fig.1. Lymphoblastic transformation of spleen cells from C57BL/10 and B10.BR mice treated with streptozotocin. Open (control) or hatched (streptozotocin-treated) columns represent ${ }^{3} \mathrm{H}$-thymidine $\left({ }^{3} \mathrm{H}-\mathrm{TdR}\right)$ incorporation by cultured spleen cells in response to PHA, PWM, concanavalin A (Con A) or without any mitogen ( - ). Small horizontal bars represent the SEM of (n) independent experiments (each in triplicate) on day 4 of culture. The lowest left panel shows the transformation of lymphocytes from $\mathrm{C} 57 \mathrm{BL} / 10$ mice treated with a high dose of streptozotocin on day 20 after administration

\section{Results}

Non-fasting glucose levels in mice following injections of streptozotocin

In both C57BL/10 and B10.BR mice, blood glucose levels were not elevated on day 6 after five consecutive administrations of multiple low doses of streptozotocin $(9.5 \pm 1.6$ and $9.8 \pm 0.9 \mathrm{mmol} / \mathrm{l}$, respectively; control mice $9.9 \pm 0.6$ and $10.8 \pm 0.9 \mathrm{mmol} / \mathrm{l})$, but were significantly elevated on day $20(18.1 \pm 1.1$ and $22.7 \pm 2.0$ $\mathrm{mmol} / \mathrm{l}$; control mice $9.6 \pm 0.5$ and $11.6 \pm 0.9 \mathrm{mmol} / 1$, $p<0.001$ ). Single high dose injections of streptozotocin caused more prominent hyperglycaemia in $\mathrm{C} 57 \mathrm{BL} / 10$ mice $(29.5 \pm 3.2 \mathrm{mmol} / 1$; control mice $9.5 \pm 0.6 \mathrm{mmol} / 1$, $p<0.001)$.

\section{Lymphoblastic transformation of spleen cells (Fig. 1)}

The relationship between the day after the first administration of streptozotocin and the ability of lymphocytes to respond to PHA, PWM and concanavalin A is shown in Figure 1. On day 6, C57BL/10 control mice showed an approximately two- two- and fourfold increase of
${ }^{3} \mathrm{H}$-thymidine incorporation in response to PHA, PWM and concanavalin $\mathrm{A}$, respectively. Mice treated with streptozotocin showed depressed responses to PHA by $40 \%(p<0.001)$, and to PWM by $45 \%(p<0.001)$ respectively, but did not to concanavalin $A$. On day 20 , the transformation remained suppressed with PHA, but recovered to the control level with PWM. On day 41, the responses to those mitogens were not different between streptozotocin-treated and control mice. With single injections of high doses streptozotocin the responses to PHA were lower than those in control mice by $31 \%$ $(p<0.02)$.

In B10.BR mice, the responses of spleen lymphocytes to concanavalin A were low on day 2 and those to PHA were significantly low on day 6 . The transformation of PWM in streptozotocin-treatment was the same as in control mice from days 2-41.

\section{Prevalence of positive ICSA (Table 1)}

In the control groups of both strains of mice, no detection of ICSA in the sera was seen. A significantly high rate of positive ICSA was observed on day 6 using multiple low doses of streptozotocin in C57BL/10 mice. 
Table 1. Prevalence of positive islet cell surface antibodies (ICSA) in two strains of mice

\begin{tabular}{|c|c|c|c|c|c|c|c|}
\hline \multirow[t]{2}{*}{ Streptozotocin } & \multirow{2}{*}{$\begin{array}{l}\text { Days after } \\
\text { the first } \\
\text { administration } \\
\text { of streptozotocin }\end{array}$} & \multicolumn{2}{|c|}{ C57BL $/ 10$ Mice } & \multicolumn{4}{|c|}{ B10.BR Mice } \\
\hline & & $\begin{array}{l}\text { Control } \\
\operatorname{IgG}(\%)\end{array}$ & $\begin{array}{l}\text { Streptozotocin } \\
\text { treated }\end{array}$ & \multicolumn{2}{|l|}{ Control } & \multicolumn{2}{|c|}{$\begin{array}{l}\text { Streptozotocin } \\
\text { treated }\end{array}$} \\
\hline $\begin{array}{l}\text { Multiple low doses (five) } \\
\text { ( } 40 \mathrm{mg} / \mathrm{kg} \text { body weight) }\end{array}$ & $\begin{array}{r}2 \\
6 \\
20 \\
41\end{array}$ & $\begin{array}{l}0(0 / 4) \\
0(0 / 5) \\
0(0 / 7) \\
0(0 / 3)\end{array}$ & $\begin{array}{c}0(0 / 5) \\
83(5 / 6)^{\mathrm{a}} \\
44(4 / 9) \\
33(2 / 6)\end{array}$ & $\begin{array}{l}0(0 / 4) \\
0(0 / 6) \\
0(0 / 5) \\
0(0 / 5)\end{array}$ & $\begin{array}{l}- \\
25(1 / 4) \\
- \\
0(0 / 2)\end{array}$ & $\begin{array}{l}20(1 / 5) \\
27(3 / 11) \\
40(2 / 5) \\
25(1 / 4)\end{array}$ & $\begin{array}{l}50(2 / 4) \\
71(5 / 7) \\
- \\
100(2 / 2)\end{array}$ \\
\hline $\begin{array}{l}\text { Single high dose } \\
\text { ( } 200 \mathrm{mg} / \mathrm{kg} \text { body weight) }\end{array}$ & 20 & $0(0 / 7)$ & $0(0 / 6)$ & - & - & - & - \\
\hline
\end{tabular}

Values in parentheses denote the number of positive observations out of the total number of samples examined. ${ }^{\mathrm{a}} p<0.05$; significance level was assessed using $\chi^{2}$ test

The positive rate of ICSA declined thereafter. In the case of B10.BR mice, the prevalence of ICSA was high on day 20 , although the differences among the days were not significant. In the group of C57BL/10 mice treated with single high doses of streptozotocin, no ICSA were detected. By examining a few indiscriminately chosen samples, IgM and IgG class ICSA were found to have contributed to ICSA elevation shortly after streptozotocin treatment.

\section{Lymphoblastic transformation to specific antigens in BIO.BR mice treated with multiple low doses of streptozotocin on day 6}

Lymphoblastic transformation to rat islet and splenic cell homogenate were tested in B10.BR mice. The islet homogenate augmented transformation in both streptozotocin-treated and control mice. Those in streptozotocin-treated mice were higher than in control mice, but were not significant. Splenic cell homogenates did not stimulate the transformation.

\section{Discussion}

This study demonstrates that impaired lymphoblastic transformation to non-specific mitogens accompanied emergence of ICSA in mice soon after treatment with multiple low doses of streptozotocin. The low responses of spleen lymphocytes to PHA, PWM and concanavalin A were detected before blood glucose levels rose. Therefore the impairment of lymphocyte function cannot be attributed to deterioration in glucose metabolism despite the report that lymphocyte responses were attenuated in poorly controlled diabetes [5]. The depressed response to PHA was also observed in single high doses of streptozotocin, but did not last until day 41 , while non-fasting blood glucose levels were high in both cases. The existence of ICSA in multiple low dose treatment but not in single high dose treatment suggested an involvement of autoimmune reactions on the extension of islet damage following the direct effect of streptozotocin, though the toxicity of streptozotocin has been said to be solely on pancreatic $\beta$ cells [6]. Additional evidence for autoimmune reactions was the finding of insulitis in mice with ICSA-positive sera. The occurrence of insulitis was prevented by administration of anti-lymphocyte sera [7], hydrocortisone [8], or total body irradiation [9], but not by administration of 3-0-methyl-D-glucose [7]. Transfer of lymphocytes from multiple low dose streptozotocin treated to congenic thymusless $\mathrm{C} 57 \mathrm{BL} / 6 \mathrm{~J}-\mathrm{nu} / \mathrm{nu}$ mice was reported to induce lymphocytic infiltration of pancreatic islets [10], and it was suggested that low dose streptozotocin treatment induced cellular immune reactions against pancreatic islets. The augmented response of lymphocytes to islet homogenate may suggest such a mechanism. Because complement-dependent cytotoxicity has been reported [11-12], the emergence of ICSA can be postulated as the trigger of further cellular response rather than the result of it.

Whereas HLA-linked genes influence the susceptibility to develop insulin-dependent diabetes, the influence of major histocompatibility complex (H-2) on streptozotocin-induced diabetes in mice is controversial [13-15]. Our data suggest that the development of hyperglycaemia did not differ in two congenic resistant lines of mice of the $\mathrm{C} 57 \mathrm{BL} / 10$ genetic background, but lymphoblastic transformations by each mitogen were slightly different between the two lines suggesting different susceptibility of lymphocyte subsets to treatment with multiple low doses streptozotocin.

Thus it might be deterioration in immunological function rather than disturbed glucose metabolism that caused the depressed response of lymphoblastic transformation in the early phase following the treatment with streptozotocin.

Acknowledgements. This study was funded in part by Grant-in-Aid for Encouragement of Young Scientists from the Ministry of Education, Science and Culture of Japan (no. 58771731). 


\section{References}

1. Lendrum R, Walker G, Gamble DR (1975) Islet-cell antibodies in juvenile diabetes mellitus of recent onset. Lancet 1: 880-883

2. Srikanta S, Ganda OP, Eisenbarth GS, Soeldner JS (1983) Isletcell antibodies and beta-cell function in monozygotic triplets and twins initially discordant for Type 1 diabetes mellitus. N Engl J Med 308: 322-325

3. Lermark A, Freedman ZR, Hofmann C, Rubenstein AH, Steiner DF, Jackson RL, Winter RJ, Traisman HS (1978) Islet-cell-surface antibodies in juvenile diabetes mellitus. N Engl J Med 299: $375-380$

4. Like AA, Rossini AA (1976) Streptozotocin-induced pancreatic insulitis: new model of diabetes mellitus. Science 193: 415-417

5. MacCuish AC, Urbaniak SJ, Campbell CJ, Duncan LJP, Irvine WJ (1974) Phytohemagglutinin transformation and circulating lymphocyte subpopulations in insulin-dependent diabetic patients. Diabetes 23: 708-712

6. Rakieten N, Rakieten ML, Nadkarni M (1963) Studies on the diabetogenic action of streptozotocin. Cancer Chemother Rep 29: 91-98

7. Rossini AA, Williams RM, Appel MC, Like AA (1978) Complete protection from low-dose streptozotocin-induced diabetes in mice. Nature 276: 182-184

8. Leiter EH, Beamer WG, Shultz LD (1983) The effect of immunosuppression on streptozotocin-induced diabetes in $\mathrm{C} 57 \mathrm{BL} / \mathrm{KsJ}$ mice. Diabetes 32: 148-155

9. Nedergaard M, Egeberg J, Kromann H (1983) Irradiation protects against pancreatic islet degeneration and hyperglycaemia following streptozotocin treatment of mice. Diabetologia 24: 382-386

10. Kiesel U, Freytag G, Biener J, Kolb H (1980) Transfer of experimental autoimmune insulitis by spleen cells in mice. Diabetologia 19: $516-520$

11. Dobersen MJ, Scharff JE, Ginsberg-Fellner F, Notkins AL (1980) Cytotoxic autoantibodies to beta cells in the serum of patients with insulin-dependent diabetes mellitus. N Engl J Med 303: 1493-1498

12. Eisenbarth GS, Morris MA, Scearce RM (1981) Cytotoxic antibodies to cloned rat islet cells in serum of patients with diabetes mellitus. J Clin Invest 67: 403-408

13. Kromann H, Lernmark A, Vestergaard BF, Egeberg J, Nerup J (1979) The influence of the major histocompatibility complex $(\mathrm{H}-2)$ on experimental diabetes in mice. Diabetologia 16: 107-114

14. Kiesel U, Kolb H (1982) Low-dose streptozotocin-induced autoimmune diabetes is under the genetic control of the major histocompatibility complex in mice. Diabetologia $23: 69-71$

15. Kromann H, Christy M, Egeberg J, Lernmark A, Nerup J (1982) Absence of $\mathrm{H}-2$ genetic influence on streptozotocin-induced diabetes in mice. Diabetologia 23: 114-118

Dr. M. Itoh

Third Department of Internal Medicine

Hamamatsu University School of Medicine

3600 Handa-cho

Hamamatsu 431-31

Japan 